\title{
Saccharothrix algeriensis sp. nov., isolated from Saharan soil
}

Correspondence

N. Sabaou

sabaou@yahoo.fr

\author{
A. Zitouni, ${ }^{1,2}$ L. Lamari, ${ }^{2,3}$ H. Boudjella, ${ }^{2,3}$ B. Badji, ${ }^{2,3}$ N. Sabaou, ${ }^{2,3}$ \\ A. Gaouar, $^{3}$ F. Mathieu, ${ }^{1}$ A. Lebrihi ${ }^{1}$ and D. P. Labeda ${ }^{4}$
}

${ }^{1}$ Ecole Nationale Supérieure Agronomique de Toulouse, INPT, Laboratoire de Génie Chimique, UMR 5503 (CNRS/INPT/UPS), 1, avenue de l'Agrobiopôle, B. P. 107, F31 326 CastanetTolosan Cedex, France

${ }^{2}$ Laboratoire de Recherche sur les Produits Bioactifs et la Valorisation de la Biomasse, Ecole Normale Supérieure de Kouba, B.P. 92, 16050 Vieux-Kouba, Algiers, Algeria

${ }^{3}$ Centre de Recherche Scientifique et Technique sur les Régions Arides, Front de l'Oued, B. P. 1682, 07000 Biskra, Algeria

${ }^{4}$ Microbial Genomics and Bioprocessing Research Unit, National Center for Agricultural Utilization Research, USDA-Agricultural Research Service, Peoria, IL 61604, USA

The taxonomic position of a soil isolate, strain SA $233^{\top}$, recovered from Saharan soil from Algeria was established using a polyphasic approach. This isolate has been previously reported to produce three novel dithiolopyrrolone antibiotics, and preliminary chemotaxonomic and morphological characteristics suggested that it was representative of a member of the genus Saccharothrix. Phylogenetic analysis of the strain from 16S rDNA sequences, along with a detailed analysis of morphological, chemotaxonomic and physiological characteristics, indicates that it belongs to the genus Saccharothrix and represents a novel species that is readily distinguished from all recognized Saccharothrix species. The name Saccharothrix algeriensis sp. nov. is proposed for the isolate, with type strain SA $233^{\top}\left(=\mathrm{NRRL} \mathrm{B}-24137^{\top}=\mathrm{DSM} 44581^{\top}\right)$.
The genus Saccharothrix, which currently comprises nine species, is characterized by type III cell wall (mesodiaminopimelic acid without glycine), rhamnose, galactose and trace mannose as diagnostic whole-cell sugars, a type PII or PIV phospholipid pattern (phosphatidyl ethanolamine and phosphatidyl hydroxyethanolamine without or with glucosamine-containing phospholipids), presence of MK-9 ( $\left.\mathrm{II}_{4}\right)$ as the predominant menaquinone and absence of mycolic acids (Labeda \& Kroppenstedt, 2000). The genera Lentzea and Lechevalieria differ from Saccharothrix by the absence of rhamnose and phosphatidyl hydroxyethanolamine or only of rhamnose, respectively, and constitute a lineage phylogenetically distinct from Saccharothrix (Labeda et al., 2001). During studies of the taxonomy and antibiotic production of actinomycetes of Saharan soils from Algeria, we obtained an isolate from soil collected in the palm grove of Adrar oasis, which we have reported to produce three novel dithiolopyrrolone antibiotics (Lamari et al., 2002). Here we describe the characterization and

Published online ahead of print on 27 February 2004 as DOI 10.1099/ ijs.0.02679-0.

Abbreviation: ISP, International Streptomyces Project.

The GenBank/EMBL/DDBJ accession number for the 16S rRNA gene sequence of strain SA $233^{\top}$ is AY054972. classification of this isolate, which is proposed as the novel species Saccharothrix algeriensis sp. nov. Isolate SA $233^{\mathrm{T}}$ has been deposited in the Agricultural Research Culture Collection and in the Deutsche Sammlung von Mikroorganismen und Zellkulturen under numbers NRRL B-24137 ${ }^{\mathrm{T}}$ and DSM $44581^{\mathrm{T}}$, respectively.

Strain SA $233^{\mathrm{T}}$ was isolated from a Saharan soil sample collected at a palm grove in Adrar, Algeria, by a dilution agar plating method using humic acid/B vitamin agar medium (Hayakawa \& Nonomura, 1987) supplemented with streptomycin sulphate $\left(10 \mu \mathrm{g} \mathrm{ml}^{-1}\right)$ and actidione $\left(50 \mu \mathrm{g} \mathrm{ml}^{-1}\right)$. Biomass for chemotaxonomic analysis was grown on yeast extract/malt extract broth, on a rotary shaker for 4 days at $30{ }^{\circ} \mathrm{C}$, harvested by centrifugation and washed twice with distilled water.

Detailed observation of mycelium morphology was performed using a scanning electron microscope (Stereoscan 260; Cambridge Instruments). Cultural characteristics observed on media from the International Streptomyces Project (ISP) (Shirling \& Gottlieb, 1966), nutrient agar and Bennett agar (Waksman, 1961) were recorded after 7-14 days incubation at $28^{\circ} \mathrm{C}$. Colours were determined according to the ISCC-NBS centroid colour chart (Kelly \& Judd, 1976). 
Tryptone/yeast extract agar (ISP medium 1), peptone/yeast extract/iron agar (ISP medium 6) and tyrosine agar (ISP medium 7) (Shirling \& Gottlieb, 1966) were used to determine melanoid pigment production. Decomposition of adenine, guanine, hypoxanthine, tyrosine and xanthine were determined as described by Gordon et al. (1974), and arbutin and aesculin decomposition, gelatin liquefaction, starch hydrolysis and nitrate reductase production were determined as described by Marchal \& Bourdon (1973). Utilization of Tween 80 and testosterone was determined by the methods of Sierra (1957) and Goodfellow (1971), respectively. Carbohydrate and organic acid assimilation were determined as described by Goodfellow (1971) and Gordon et al. (1974), respectively. Sensitivity to lysozyme was studied using the method of Gordon \& Barnett (1977). Sensitivity to phenol, potassium tellurite, sodium azide, sodium chloride and crystal violet were determined on glucose/yeast extract agar as described by Athalye et al. (1985). Growth at different temperatures and $\mathrm{pH}$ and in the presence of various antibiotics was determined on the same media.

The isomeric form of diaminopimelic acid and predominant whole-cell sugars were detected following standard procedures described by Becker et al. (1964) and Lechevalier \& Lechevalier (1970). Phospholipids and mycolic acids were analysed using the procedure of Minnikin et al. (1977, 1980). The fatty acid profile was determined by the method of Grund \& Kroppenstedt (1989).

Genomic DNA for sequencing was isolated, purified and sequenced following the procedures described by Labeda \& Kroppenstedt (2000). The $16 \mathrm{~S}$ rDNA sequence was manually aligned with actinomycete reference sequences obtained from the Ribosomal Database Project (Maidak et al., 1994) and GenBank in the ARB software environment for sequence data developed by W. Ludwig and O. Strunk (Lehrstuhl für Mikrobiologie, University of Munich, Germany). Evolutionary distances were calculated within ARB by the method of Kimura (1980) and linkages by the neighbour-joining method of Saitou \& Nei (1987); maximum-parsimony and maximum-likelihood analyses were also performed in ARB. The topologies of the trees resulting from neighbour-joining and maximum-parsimony analyses were evaluated by bootstrap analysis of the data with 500 resamplings.

Genomic DNA was isolated as described by Labeda (1998) and DNA-DNA relatedness between strains was determined spectrophotometrically in $5 \times$ SSC $(1 \times$ SSC is $0 \cdot 15 \mathrm{M}$ sodium chloride and $0.015 \mathrm{M}$ sodium citrate) and $20 \%$ dimethyl sulphoxide at $66^{\circ} \mathrm{C}$ (melting point $-23^{\circ} \mathrm{C}$ ) by the method of De Ley et al. (1970).

Strain SA $233^{\mathrm{T}}$ exhibited good growth on ISP-2, ISP-5 and Bennett agar, with well-developed, yellow orange aerial mycelium that fragmented into rod-shaped spores. The spores had a smooth surface (Fig. 1) and were non-motile. No endospores, sporangia, sclerotia or synnemata were

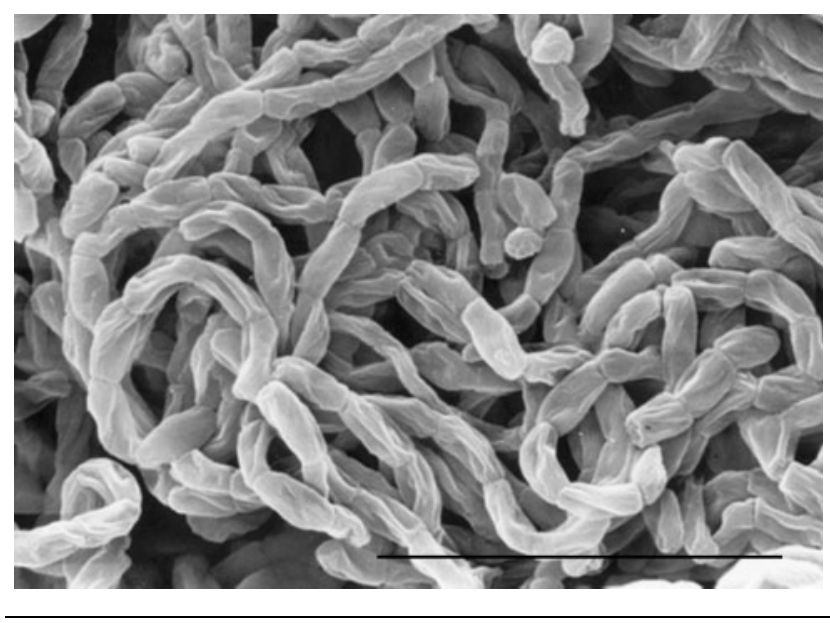

Fig. 1. Scanning electron micrograph of spore chains of strain SA $233^{\top}$ grown on yeast extract/malt extract agar (ISP medium 2) for 10 days at $30^{\circ} \mathrm{C}$. Bar, $5 \mu \mathrm{m}$.

observed. Growth was moderate on ISP-3 and nutrient agar and poor on ISP-4 agar, with poorly developed aerial mycelium. The substrate mycelium exhibited little or no fragmentation on either solid or liquid media. The substrate mycelium was vivid yellow, orange yellow or yellow brown. A bright yellow soluble pigment was produced on ISP-2 and ISP-3 agar, whereas a yellow brown soluble pigment was produced on Bennett agar. The isolate did not produce melanoid pigments on ISP-1, ISP-6 or ISP-7 agar.

Cell-wall hydrolysates contained meso-diaminopimelic acid but not glycine and whole-cell hydrolysates contained galactose, mannose and rhamnose, in addition to glucose and ribose, typical of cell wall type III (Lechevalier \& Lechevalier,

Table 1. Fatty acid profile of Saccharothrix algeriensis sp. nov. SA $233^{\top}$

Fatty acid identities were determined from the Microbial Identification System software (MIDI Inc.) peak-naming table.

\begin{tabular}{|c|c|}
\hline Fatty acid & Percentage of total \\
\hline iso- $\mathrm{C}_{14: 0}$ & $3 \cdot 46$ \\
\hline iso- $\mathrm{C}_{15: 0}$ & $10 \cdot 06$ \\
\hline anteiso- $\mathrm{C}_{15: 0}$ & $1 \cdot 80$ \\
\hline $\mathrm{C}_{15: 1} \mathrm{~B}$ & $2 \cdot 11$ \\
\hline iso- $\mathrm{C}_{16: 1} \mathrm{H}$ & $14 \cdot 00$ \\
\hline iso- $\mathrm{C}_{16: 0}$ & $31 \cdot 26$ \\
\hline cis-9- $\mathrm{C}_{16: 1}$ & $3 \cdot 92$ \\
\hline 9?-Methyl- $\mathrm{C}_{16: 0}$ & $3 \cdot 42$ \\
\hline iso- $\mathrm{C}_{17: 0}$ & $1 \cdot 65$ \\
\hline anteiso- $\mathrm{C}_{17: 0}$ & $3 \cdot 00$ \\
\hline cis-9- $\mathrm{C}_{17: 1}$ & $7 \cdot 37$ \\
\hline iso-2-hydroxy- $\mathrm{C}_{16: 0}$ & $10 \cdot 44$ \\
\hline 10-Methyl-C $\mathrm{C}_{17: 0}$ & $1 \cdot 13$ \\
\hline
\end{tabular}


1970). Diagnostic phospholipids detected were phosphatidyl ethanolamine (with phosphatidyl hydroxy-ethanolamine) and glucosamine-containing phospholipids, corresponding to phospholipids type PIV (Lechevalier et al., 1977). Mycolic acids were not detected. The predominant fatty acid was iso-branched hexadecanoate (iso- $\mathrm{C}_{16: 0}$ ), and significant amounts of iso- $\mathrm{C}_{16: 1}$ (position of the unsaturation unknown), iso-2-hydroxy- $\mathrm{C}_{16: 0}$ and iso- $\mathrm{C}_{15: 0}$ fatty acids were also present. The cellular fatty acid composition of the strain SA $233^{\mathrm{T}}$ is given in Table 1. The morphological and chemical characteristics described above clearly support the placement of strain SA $233^{\mathrm{T}}$ within the genus Saccharothrix.

Strain SA $233^{\mathrm{T}}$ is physiologically different from other recognized Saccharothrix species, as can be seen from the differential physiological characteristics given in Table 2 . In addition, a comparison with the physiologically nearest species, Saccharothrix australiensis NRRL $11239^{\mathrm{T}}$, showed differences in characteristics of the cultures (colour of aerial and substrate mycelia and colour of diffusible pigments) and in the utilization of cellobiose, dextrin, mannose, sorbitol, erythritol, sodium acetate, sodium citrate and sodium propionate. Complete physiological characteristics of strain SA $233^{\mathrm{T}}$ are given in the formal description below.

The phylogenetic relationship between strain SA $233^{\mathrm{T}}$ and the other recognized species of Saccharothrix is seen in the neighbour-joining dendrogram in Fig. 2. Maximumparsimony calculation resulted in a similar tree topology. The similarity of the 16S rDNA sequence of strain SA $233^{\mathrm{T}}$ to those of the other species of the genus Saccharothrix ranged from $97 \cdot 5$ to $98 \cdot 8 \%$, with Saccharothrix australiensis NRRL $11239^{\mathrm{T}}$ having the closest match. Other species within the genus Saccharothrix that have been determined to be distinct based on DNA-DNA relatedness have $16 \mathrm{~S}$ rRNA gene sequence similarities in this range of values.

Table 2. Differential properties of Saccharothrix algeriensis sp. nov. compared with recognized species of the genus Saccharothrix

Strains: 1, S. algeriensis sp. nov. SA $233^{\mathrm{T}} ; 2$, S. australiensis NRRL $11239^{\mathrm{T}} ; 3$, S. coeruleofuscus DSM 43679 ${ }^{\mathrm{T}}$; 4, S. coeruleoviolacea DSM $43935^{\mathrm{T}}$; 5, S. espanaensis NRRL $15764^{\mathrm{T}}$; 6, S. longispora DSM $43749^{\mathrm{T}} ; 7$, S. mutabilis subsp. mutabilis NRRL B-16077 ${ }^{\mathrm{T}}$; 8, S. mutabilis subsp. capreolus DSM 40225 ${ }^{\mathrm{T}}$; 9, S. syringae DSM 43886 ${ }^{\mathrm{T}}$; 10, S. tangerinus JCM $10302^{\mathrm{T}}$; 11, S. texasensis NRRL B-16134 ${ }^{\mathrm{T}}$. Data for reference species were taken from Labeda (2002). -, Negative reaction; +, positive reaction; w, weak positive reaction.

\begin{tabular}{|c|c|c|c|c|c|c|c|c|c|c|c|}
\hline Characteristic & 1 & 2 & 3 & 4 & 5 & 6 & 7 & 8 & 9 & 10 & 11 \\
\hline Adenine & - & - & - & - & - & + & - & - & - & - & - \\
\hline Starch & - & - & + & - & - & + & + & + & + & + & + \\
\hline Tyrosine & + & + & - & - & - & + & + & + & + & + & + \\
\hline \multicolumn{12}{|l|}{ Production of: } \\
\hline Nitrate reductase & + & + & - & + & $\mathrm{w}$ & + & + & - & - & - & + \\
\hline Assimilation of citrate & + & - & - & + & $\mathrm{W}$ & + & + & - & - & + & - \\
\hline \multicolumn{12}{|l|}{ Acid from: } \\
\hline Arabinose & - & - & + & + & - & + & + & + & + & + & + \\
\hline Dextrin & - & + & + & + & - & + & + & + & + & + & + \\
\hline Rhamnose & - & - & + & + & - & + & - & - & + & + & + \\
\hline Sorbitol & - & + & + & - & - & - & - & - & - & + & - \\
\hline Sucrose & - & - & + & - & + & + & + & - & + & + & + \\
\hline Xylose & - & - & + & + & $\mathrm{W}$ & + & + & + & + & + & + \\
\hline Methyl $\alpha$-D-glucoside & - & - & + & W & - & - & + & - & - & $\mathrm{W}$ & + \\
\hline \multicolumn{12}{|c|}{ Growth in the presence of: } \\
\hline $4 \% \mathrm{NaCl}$ & + & + & + & - & + & + & - & + & + & + & - \\
\hline $5 \% \mathrm{NaCl}$ & - & - & + & - & - & + & - & + & + & $\mathrm{W}$ & - \\
\hline \multicolumn{12}{|l|}{ Growth at: } \\
\hline $37^{\circ} \mathrm{C}$ & + & + & + & + & + & + & + & + & + & - & + \\
\hline $45^{\circ} \mathrm{C}$ & + & + & + & + & - & - & + & + & + & - & - \\
\hline
\end{tabular}




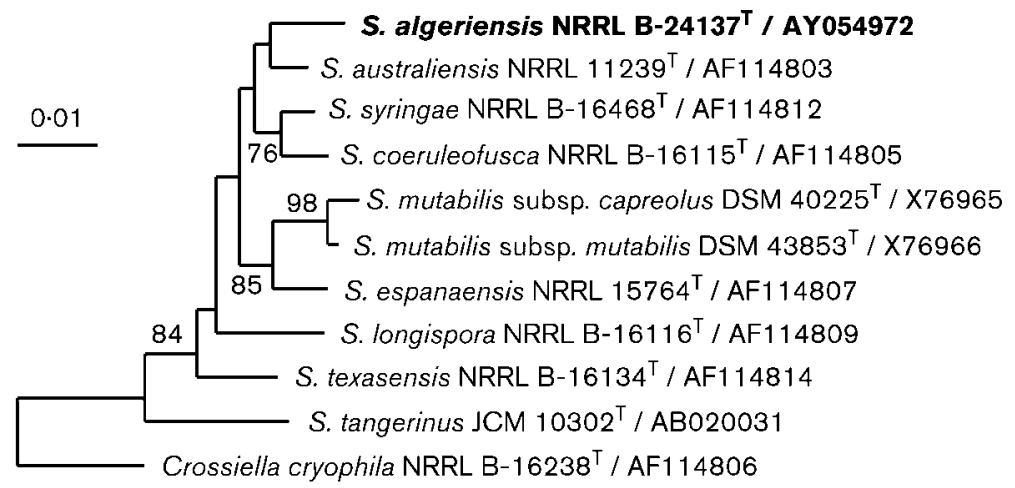

Fig. 2. Phylogenetic tree for species of the genus Saccharothrix calculated from almost complete 16S rDNA sequences using Kimura's evolutionary distance methods (Kimura, 1980) and the neighbour-joining method of Saitou \& Nei (1987). This illustrates the taxonomic position of Saccharothrix algeriensis sp. nov. NRRL $B-24137^{\top}\left(=S A 223^{\top}\right)$ relative to the other species of the genus. Bar, 0.01 nucleotide substitutions per site.

Strain SA $233^{\mathrm{T}}$ was determined to have only $55.9 \%$ genomic DNA-DNA relatedness (based on a mean of duplicate determinations) to S. australiensis NRRL $11239^{\mathrm{T}}$, the phylogenetically closest species of the genus Saccharothrix, which is clearly below the $70 \%$ relatedness guideline proposed by Wayne et al. (1987) for the delineation of separate species. All of the data support the designation of strain SA $233^{\mathrm{T}}$ as representing a novel species of the genus Saccharothrix, for which we propose the name Saccharothrix algeriensis sp. nov.

\section{Description of Saccharothrix algeriensis sp. nov.}

Saccharothrix algeriensis (al.ger.i.en'sis. N.L. fem. adj. algeriensis of Algeria, where the type strain originated).

Aerobic, Gram-positive, catalase-positive. Forms a copious yellow orange aerial mycelium that fragments into rodshaped spores. Spore surface is smooth. Substrate mycelium is vivid yellow, orange yellow or yellowish brown. A bright yellow soluble pigment is produced but no melanoid pigment. Growth occurs between 18 and $45^{\circ} \mathrm{C}$ but not at $48^{\circ} \mathrm{C}$. Utilizes D-fructose, D-galactose, D-glucose, maltose, D-trehalose, glycerol, acetate, citrate, pyruvate and succinate as carbon sources, but not L-arabinose, D-cellobiose, dextrin, D-lactose, D-mannose, D-melezitose, melibiose, methyl $\alpha$-D-glucoside, D-raffinose, L-rhamnose, D-ribose, sucrose, D-xylose, adonitol, dulcitol, meso-erythritol, mesoinositol, D-mannitol, D-sorbitol, benzoate, butyrate, oxalate, propionate and tartrate. Aesculin, casein, gelatin, Tween 80 and tyrosine are hydrolysed. No hydrolysis of adenine, arbutin, guanine, hypoxanthine, starch, testosterone or xanthine. Nitrate reductase is produced. Growth occurs at $\mathrm{pH} 5$ and 9 and in the presence of $0.005 \%$ lysozyme, $0.01 \%$ potassium tellurite, $0.001 \%$ crystal violet and $0.05 \%$ phenol. Growth does not occur in the presence of $5 \% \mathrm{NaCl}, 0.001 \%$ sodium azide and $0 \cdot 1 \%$ phenol. Susceptible to chloramphenicol $\left(25 \mu \mathrm{g} \mathrm{ml}^{-1}\right)$, erythromycin $\left(10 \mu \mathrm{g} \mathrm{ml}^{-1}\right)$, kanamycin $\left(25 \mu \mathrm{g} \mathrm{ml}^{-1}\right)$, novobiocin $\left(10 \mu \mathrm{g} \mathrm{ml}^{-1}\right)$ and penicillin $\left(10 \mu \mathrm{g} \mathrm{ml}^{-1}\right)$ but resistant to cycloserin $\left(10 \mu \mathrm{g} \mathrm{ml}^{-1}\right)$, gentamicin $\left(5 \mu \mathrm{g} \mathrm{ml}^{-1}\right)$, oxytetracycline $\left(25 \mu \mathrm{g} \mathrm{ml}^{-1}\right)$, rifampicin $\left(5 \mu \mathrm{g} \mathrm{ml}^{-1}\right)$, streptomycin $\left(10 \mu \mathrm{g} \mathrm{ml}^{-1}\right)$ and vancomycin $\left(5 \mu \mathrm{g} \mathrm{ml}^{-1}\right)$. Type III cell wall (meso-diaminopimelic acid, galactose, mannose and rhamnose in whole-cell hydrolysates). Phospholipids type PIV (phosphatidyl ethanolamine and glucosaminecontaining phospholipids). The predominant fatty acid is iso- $\mathrm{C}_{16: 0}(31 \cdot 26 \%)$, followed by iso- $\mathrm{H}-\mathrm{C}_{16: 0}(14 \cdot 00 \%)$, iso-2-hydroxy- $\mathrm{C}_{16: 0}(10 \cdot 44 \%)$ and iso- $\mathrm{C}_{15: 0}(10 \cdot 06 \%)$. Mycolic acids are absent.

The type strain is SA $233^{\mathrm{T}}\left(=\mathrm{NRRL}\right.$ B $-24137^{\mathrm{T}}=\mathrm{DSM}$ $44581^{\mathrm{T}}$ ), isolated from a Saharan soil sample collected at a palm grove in Adrar, Algeria. The species description is based on a single strain and hence serves as the strain description.

\section{Acknowledgements}

This work was funded by projects of the CMEP (Comite Mixte d'Evaluation et de Prospective de Coopération Interuniversitaire Franco-Algérienne, France) no. 02 MDU 564 and ANDRU (Agence Nationale pour le Développement de la Recherche Universitaire, Algérie) no. AN19802. We also acknowledge the cooperation and cultural action department of the French Embassy at Algiers, Algeria. We thank E. N. Hoekstra for help with DNA isolation and purification and $16 \mathrm{~S}$ rRNA gene sequence determinations.

\section{References}

Athalye, M., Goodfellow, M., Lacey, J. \& White, R. P. (1985). Numerical classification of Actinomadura and Nocardiopsis. Int J Syst Bacteriol 35, 86-98.

Becker, B., Lechevalier, M. P., Gordon, R. E. \& Lechevalier, H. A. (1964). Rapid differentiation between Nocardia and Streptomyces by paper chromatography of whole-cell hydrolysates. Appl Microbiol 12, 421-423.

De Ley, J., Cattoir, H. \& Reynaerts, A. (1970). The quantitative measurement of DNA hybridization from renaturation rates. Eur J Biochem 12, 133-142.

Goodfellow, M. (1971). Numerical taxonomy of some nocardioform bacteria. J Gen Microbiol 69, 33-80.

Gordon, R. E. \& Barnett, D. A. (1977). Resistance to rifampin and lysozyme of strains of some species of Mycobacterium and Nocardia as a taxonomic tool. Int J Syst Bacteriol 27, 176-178.

Gordon, R. E., Barnett, D. A., Handerhan, J. E. \& Pang, C.-H. N. (1974). Nocardia coeliaca, Nocardia autotrophica, and the nocardin strain. Int J Syst Bacteriol 24, 54-63.

Grund, E. \& Kroppenstedt, R. M. (1989). Transfer of five Nocardiopsis species to the genus Saccharothrix Labeda et al., 1984. Syst Appl Microbiol 12, 267-274. 
Hayakawa, M. \& Nonomura, H. (1987). Humic acid-vitamin agar, a new medium for the selective isolation of soil actinomycetes. J Ferment Technol 65, 501-509.

Kelly, K. L. \& Judd, D. B. (1976). Color. Universal Language and Dictionary of Names (National Bureau of Standards Special Publication 440). Washington, DC: US Department of Commerce.

Kimura, M. (1980). A simple method for estimating evolutionary rates of base substitutions through comparative studies of nucleotide sequences. J Mol Evol 16, 111-120.

Labeda, D. P. (1998). DNA relatedness among the Streptomyces fulvissimus and Streptomyces griseoviridis phenotypic cluster groups. Int J Syst Bacteriol 48, 829-832.

Labeda, D. P. (2002). The family Actinosynnemataceae. In The Prokaryotes: an Evolving Electronic Resource for the Microbiological Community, 3rd edn, release 3.9, 1 April 2002. Edited by M. Dworkin et al. New York: Springer. http://www.prokaryotes.com

Labeda, D. P. \& Kroppenstedt, R. M. (2000). Phylogenetic analysis of Saccharothrix and related taxa: proposal for Actinosynnemataceae fam. nov. Int J Syst Evol Microbiol 50, 331-336.

Labeda, D. P., Hatano, K., Kroppenstedt, R. M. \& Tamura, T. (2001). Revival of the genus Lentzea and proposal for Lechevalieria gen. nov. Int J Syst Evol Microbiol 51, 1045-1050.

Lamari, L., Zitouni, A., Boudjella, H., Badji, B., Sabaou, N., Lebrihi, A., Lefebvre, G., Seguin, E. \& Tillequin, F. (2002). New dithiolopyrrolone antibiotics from Saccharothrix sp. SA 233. I. Taxonomy, fermentation, isolation, and biological activities. J Antibiot 55, 696-701.

Lechevalier, M. P. \& Lechevalier, H. A. (1970). Chemical composition as a criterion in the classification of aerobic actinomycetes. Int J Syst Bacteriol 34, 435-444.
Lechevalier, M. P., de Bièvre, C. \& Lechevalier, H. A. (1977). Chemotaxonomy of aerobic actinomycetes: phospholipid composition. Biochem Syst Ecol 5, 249-260.

Maidak, B. L., Larsen, N., McCaughey, M. J., Overbeek, R., Olsen, G. J., Fogel, K., Blandy, J. \& Woese, C. R. (1994). The Ribosomal Database Project. Nucleic Acids Res 22, 3485-3487.

Marchal, N. \& Bourdon, J. L. (1973). Milieux de Culture et Identification Biochimique des Bactéries. Paris: Doin (in French).

Minnikin, D. E., Patel, P. V., Alshamaony, L. \& Goodfellow, M. (1977). Polar lipid composition in the classification of Nocardia and related bacteria. Int J Syst Bacteriol 27, 104-107.

Minnikin, D. E., Hutchinson, I. G., Caldicott, A. B. \& Goodfellow, M. (1980). Thin-layer chromatography of methanolysates of mycolic acid-containing bacteria. J Chromatogr 188, 221-233.

Saitou, N. \& Nei, M. (1987). The neighbor-joining method: a new method for reconstructing phylogenetic trees. Mol Biol Evol 4, 406-425.

Shirling, E. B. \& Gottlieb, D. (1966). Methods for characterization of Streptomyces species. Int J Syst Bacteriol 16, 313-340.

Sierra, G. (1957). A simple method for the detection of lipolytic activity of micro-organisms and some observations on the influence of contact between the cells and fatty substrates. Antonie van Leeuwenhoek 23, 15-22.

Waksman, S. A. (1961). Classification, identification, and descriptions of genera and species. In The Actinomycetes, vol. 2, pp. 331332. Baltimore: Williams \& Wilkins.

Wayne, L. G., Brenner, D. J., Colwell, R. R. \& 9 other authors (1987). Report of the ad hoc committee on reconciliation of approaches to bacterial systematics. Int J Syst Bacteriol 37, 463-464. 